GAWEe JANIK

Uniwersytet Śląski

\title{
Ocalali z potopu. Księga rozbitków Sydora Reya jako robinsonada holokaustowa
}

Próba odczytania utworu o Zagładzie jako narracji realizującej wzorzec robinsonady mogłaby zostać uznana za pomysł co najmniej karkołomny, by nie powiedzieć całkowicie bezzasadny. W polskiej literaturze poruszającej temat Holokaustu znajduje się jednak utwór, który, jak się wydaje, umożliwia, a wręcz sugeruje, właśnie taki tryb lekturowy. Mam tu na myśli właściwie zupełnie nieznany współczesnemu czytelnikowi zbiór opowiadań Sydora Reya ${ }^{1}$ Księga rozbitków, którego już sam tytuł, w związku z użyciem słowa rozbitek, budzić może skojarzenia $\mathrm{z}$ bodaj najsłynniejszym rozbitkiem $\mathrm{w}$ historii literatury Robinsonem Crusoe.

Sydor Rey, a właściwie Isak Reis lub Izydor Reiss, bo tak brzmiało jego prawdziwe, żydowskie imię i nazwisko, urodził się w 1908 roku w Wojniłowie na Podkarpaciu. Przed wojną studiował prawo we Lwowie, a następnie w Warszawie. Mając 21 lat, zadebiutował opowiadaniem Czarne listy opublikowanym

1 Cała twórczość autora stanowi, używając określenia Sławomira Buryły, temat nieopisany. W jedynym powstałym do tej pory artykule dotyczącym pisarstwa Reya wspomniany już Buryła w następujący sposób pisze o autorze Księgi rozbitków: „Nie tylko przeciętny czytelnik, ale i zawodowy krytyk miałby dziś problem z przypomnieniem sobie postaci i dzieła Sydora Reya. Trudno jest w słownikach czy kompendiach naukowych znaleźć jego biogram" (Buryła 63). 
w tygodniku Świat, Dom i Szkoła. Pracował wówczas jako wychowawca w sierocińcu prowadzonym przez Janusza Korczaka (wspomnienia z tego okresu odnaleźć można w opowiadaniu Anioł stróż z Księgi rozbitków). W tym czasie dołączył także do grupy literackiej Przedmieście. Debiut powieściowy Reya przypada na rok 1937, kiedy to ukazała się jego książka Kropiwniki. W 1939 roku wyjechał do Stanów Zjednoczonych, by wziąć udział w Światowym Kongresie Pisarzy na Rzecz Pokoju i Demokracji oraz zebrać materiały do nowej powieści dotyczącej mieszkańców nowojorskiego Lower Eeast Side, która jednak nigdy nie ukazała się drukiem. Podczas pobytu w usA do pisarza dotarły wieści o wybuchu II wojny światowej. Resztę swojego życia spędził w Nowym Jorku. W roku 1945 ukazał się jego tomik poetycki Pieśni mówione (Nowy Jork: Saint Marks Printing Corporation), w 1959 roku opublikowany został zbiór opowiadań Księga rozbitków (Warszawa: Czytelnik), zaś w 1967 roku na księgarskie półki trafił drugi tom wierszy Reya - Własnymi słowami (Londyn: Oficyna Poetów). Drukował on w polsko-amerykańskiej prasie oraz wydawanym w Londynie tygodniku Wiadomości. Tłumaczenia jego wierszy oraz opowiadań ukazywały się w Stanach Zjednoczonych. Autor zmarł w 1979 roku.

W niniejszym artykule skupię się na wydanej w 1959 roku Księdze rozbitków, zbiorze siedemnastu opowiadań stanowiących zapis losów Żydów ocalałych z Zagłady, którzy po wojnie znaleźli się w Nowym Jorku. Przewodnikiem po historiach tytułowych rozbitków jest pierwszoosobowy narrator. Bez trudu możemy utożsamić go z samym Reyem. Moim celem będzie wskazanie elementów, które pozwoliłyby uznać tom za specyficzny rodzaj robinsonady holokaustowej.

W Słowniku rodzajów i gatunków literackich pod redakcją Grzegorza Gazdy przeczytać możemy, że robinsonada, to

typ utworów, głównie powieści, które schematem fabularnym i konstrukcyjnym nawiązują do głównego wątku Przypadków Robinsona Crusoe (1719) autorstwa Daniela Defoe. Bohater (rzadziej grupa bohaterów) zostaje odizolowany od świata (najczęściej w wyniku katastrofy) i skazany na samotniczą egzystencję w dzikiej przestrzeni, w której walcząc z żywiołem przyrody - tworzy warunki cywilizowanego życia (Gazda 939).

Jadwiga Ruszała, która robinsonadom poświeciła dwie monografie - Robinson $w$ literaturze polskiej. Teoria - historia - recepcja (1998) oraz Robinsonada $w$ literaturze polskiej. Teoria - typologia - bohater - natura (2000), proponuje, by ten rodzaj tekstów 
traktować jako zestrój robinsonotopów, swoistych motywów, dających się przenieść z utworu do utworu, co odbywać się może za pomocą różnych technik narracyjnych. Powtarzalność podstawowych części składowych (robinsonotopów) to stała zasada robinsonad (Ruszała 2000: 20).

Wśród klasycznych robinsonotopów, wyodrębnionych na podstawie lektury powieści Daniela Defoe, znajdują się, zdaniem badaczki:

ucieczka bohatera $\mathrm{z}$ domu, rozbicie się okrętu, pobyt bohatera w wyniku katastrofy na bezludnej wyspie, wysiłki rozbitka na rzecz poprawy warunków swojej egzystencji, radzenie sobie w nowych okolicznościach, powrót do cywilizacji lub decyzja pozostanie na wyspie (Ruszała 2000: 20).

Należy odnotować, że wśród literackich realizacji tejże odmiany gatunkowej rozróżnić można zarówno „robinsonady sensu stricto” (Ruszała 2000: 27), jak i utwory robinsonopodobne, w których robinsonotopy mogą występować selektywnie oraz ulegać uproszczeniem i przekształceniom.

Już tytułowa kategoria rozbitków, na którą zdecydował się Rey, budzi w czytelniku skojarzenia robinsonowskie. W definicji słownikowej rozbitek to „ten, kto uratował się z rozbitego okrętu” (Sobol 845). Zarówno Słownik współczesnego języka polskiego pod redakcją Bogusława Dunaja, jak i Wielki słownik języka polskiego redagowany przez Piotra Żmigrodzkiego, notują jeszcze jedno znaczenie słowa - chodzi o rozbitka życiowego, a więc osobę, „która przeżyła wiele nieszczęść, tracąc to, co osiągnęła wcześniej” (Dunaj 954).

Bohaterowie zbioru opowiadań Reya zdają się łączyć w sobie obydwa wyżej wymienione znaczenia. Jako ocalali z Zagłady są oni „rozbitkami życiowymi” cudem przeżyli Holokaust, podczas którego stracili jednak swoich bliskich i musieli uciekać ze swych domów. W sposób metaforyczny widzieć można w nich także rozbitków w znaczeniu pierwszym i podstawowym - uciekając przed śmiercią, przebyli oni podróż transoceaniczną, a wojenna zawierucha wyrzuciła ich na brzeg Stanów Zjednoczonych. Podobnie jak w przypadku stanowiącej jeden z robinsonotopów katastrofy statku, tak i w przypadku Zagłady tylko nielicznym udało się ją przetrwać. Robinson Crusoe, tak jak Żydzi ocalali z Holokaustu, „został niejako z grobu uratowany” (Defoe 30).

Kondycja rozbitka zarówno u Defoe, jak i u Reya nierozerwalnie wiąże się $\mathrm{z}$ pewnym zagrożeniem. Radość $\mathrm{z}$ ocalenia bywa na tyle obezwładniająca, że paradoksalnie prowadzić może do śmierci. Autor Księgi rozbitków w następujący 
sposób wypowiada się na temat Żydówki Jadwigi, której udało się przeżyć Zagładę: „Śmierć przyszła po nią w przebraniu. Rozbitek na widok lądu odczuwa ulgę i wśród tej chwilowej ulgi śmierć objawia mu się w postaci odpoczynku tak przekonywająco, że ona mu się wydaje życiem. Poddaje się i idzie na dno po odpoczynek, po życie..." (Rey 37). Podobny fragment odnaleźć możemy w Robinsonie Crusoe:

[...] rozumiem, dlaczego przesyłając ułaskawienie skazanemu na śmierć w chwili, gdy już oczekiwał zgonu, przydają także cyrulika dla puszczenia krwi w obawie, żeby to nagłe zachwycanie tamując bicie jego serca nie stało się zabójcze. Nagła radość może bowiem równie łatwo zahamować popęd żywotny, jak niespodziane strapienie (Defoe 30).

Stany Zjednoczone są dla żydowskich bohaterów Księgi rozbitków niczym Robinsonowska odległa i zupełnie obca wyspa. Tubylców, a więc w przypadku opowiadań Reya Amerykanów, cechuje dystans w stosunku do przybyłych z Europy Żydów. Stary kontynent i rozgrywające się na nim wydarzenia wojenne był dla nich tak trudne do zrozumienia, „jak gdyby sprawy rozgrywały się na księżycu" (Rey 188).

Narrator Księgi rozbitków wielokrotnie wyraża zdziwienie w związku z tym, że na swojej drodze spotyka ocalałych z Zagłady. Pomimo że on sam uniknął Holokaustu, trudno mu uwierzyć w to, że tytułowych rozbitków jest więcej. Że wyspa, na którą trafił przed wojną, powoli zapełnia się znajomymi twarzami z przeszłości. Na widok Michała, bohatera opowiadania Wesele $w$ Waszyngtonie, narrator kilkakrotnie powtórzy z niedowierzaniem: „A więc żyjesz” (Rey 14), dodając później w myślach: „Nie sądziłem, że ocaleje, że przetrwa w Polsce lata wojenne" (Rey 14). Pomimo spotkania z dawnym znajomym oraz wymiany z nim kilku listów, narratorowi wciąż trudno uwierzyć, że mężczyzna naprawdę żyje: „ "A może Michał zginął?» - myślałem z uporem, jak gdyby według mnie powinien był zginąć” (Rey 25). Gdy tuż po roku 1945 narrator otrzymuje list od swojej pierwszej miłości - Stelli - w którym kobieta prosi go o kontakt, mężczyzna nie odpisuje, ponieważ, jak mówi, „to było zaraz po wojnie i chyba nie wierzyłem, że w ogóle ktoś pozostał przy życiu, jeszcze nie ochłonąłem był z pierwszego wstrząsu” (Rey 166). W ocalałych postawa narratora budzi pobłażanie, a czasem również zdenerwowanie, jak w przypadku Jadwigi, bohaterki opowiadania Nekrofilia, która w złości wykrzykuje do innego ocalałego: „Panie Karolu - zawołała w końcu, wskazując na mnie - on nam bierze za złe, żeśmy pozostali przy życiu” (Rey 36). Także sami rozbitkowie zdają się nie dowierzać, że udało im się ujść z życiem z Za- 
głady. Świadczyć może o tym chociażby zachowanie Michała, który podczas rozmowy z narratorem „wstał z ławki, przeciągnął się, jak gdyby stwierdzał, że ma żywe ciało, i znów usiadł” (Rey 18-19). Postawa mężczyzny przypomina niedowierzanie, które charakteryzowało Robinsona Crusoe po tym, jak udało mu się przeżyć katastrofę statku: „Chodziłem po wybrzeżu podnosząc dłonie ku niebu, cały zatopiony w myślach o moim ocaleniu [...]. - Boże! - mówiłem sobie w duchu. - Jakże to możliwe, bym mógł taką przestrzeń przepłynąć do brzegu?" (Defoe 30).

Holokaust określany jest na kartach Księgi rozbitków mianem „katastrofy” (Rey 26), „kataklizmu” (Rey 11) oraz „klęski” (Rey 26). Choć w rozumieniu słownikowym wszystkie te pojęcia funkcjonują na zasadzie synonimów, to warto przyjrzeć się im nieco bliżej. Katastrofa jako „wydarzenie powodujące tragiczne skutki” (Sobol 314) kojarzona jest często z katastrofą lotniczą, morską czy też klimatyczną. Kataklizm rozumiemy przede wszystkim jako „gwałtowne i nagłe zmiany w przyrodzie powodujące ogromne zniszczenia” (Dunaj 368). Kataklizm wiąże się więc z siłami natury, żywiołami takimi jak powódź, trzęsienie ziemi czy wybuch wulkanu. Z kolei klęska to „przegrana wojna, bitwa lub rywalizacja” (Sobol 325), ale także klęska żywiołowa - „klęska głodu, suszy, powodzi, pożarów” (Dunaj 382).

Każde z użytych przez Reya określeń łączyłoby Zagładę z katastrofami naturalnymi. Tego typu typu metonimizacja Holokaustu wskazywałaby na możliwość badania Księgi rozbitków z perspektywy środowiskowej historii Zagłady, a więc, mówiąc za Jackiem Małczyńskim, dziedziny holocaust studies, która „interesuje się rozmaitymi wyobrażeniami, znaczeniami i wartościami związanymi z przyrodą w kontekście Zagłady” (Małczyński 9).

Co ciekawe, ten typ przedstawiania Holokaustu łączyłby wydany w 1959 roku zbiór opowiadań Reya z dużo późniejszymi, opublikowanymi w 1987 powieściami Tadeusza Konwickiego (Bohiń), Andrzeja Kuśniewicza (Nawrócenie), Piotra Szewca (Zagłada) oraz Pawła Huellego (Weiser Dawidek), w których Holokaust przedstawiony został pod postacią burzy, wichury czy powodzi (zob. Tomczok). Niszczycielska moc żywiołu, który metonimizuje Zagładę, wyrzuca tytułowych rozbitków z opowiadań Reya na brzeg robinsonowskiej wyspy, która okazuje się odległą, zaoceaniczną Ameryką.

Wykorzystane w Księdze rozbitków obrazowanie Zagłady jako katastrofy, kataklizmu czy klęski jeszcze silniej łączyć będzie się z robinsonotopem związanym z katastrofą morską i rozbiciem się okrętu, gdy pod uwagę weźmie się fakt, iż w opowiadaniach Reya znajdziemy nawiązania do biblijnego potopu. Narrator-rozbitek powie o sobie, że „ocalał i znalazł się w Nowym Jorku jak Noe na Araracie" (Rey 99). 
Tropy i figury biblijne obecne są w wielu tekstach o Zagładzie. Zdaniem Aliny Molisak i Aleksandry Sekuły, autorzy sięgają „po język Biblii, traktując go jako narzędzie, które ma pomóc wyrazić Szoa” (Molisak, Sekuła 108). Badaczki wymieniają kilka najczęściej wykorzystywanych nawiązań, wśród których zdaje się dominować przypowieść o Hiobie. Znamienne, że w artykule Molisak i Sekuły ani raz nie pojawia się odniesienie do starotestamentowych dziejów Noego i opisanego w Księdze Rodzaju potopu. Według niektórych czynienie porównań do historii biblijnych jest jednak w przypadku narracji dotyczących Holokaustu zabiegiem niestosownym. Michał Głowiński w Czarnych sezonach pisał:

W historiach, które złożyły się na Zagładę, nie ma analogii nawet do najokrutniejszych epizodów z Biblii. Księga, także w tych fragmentach, w których nie ustrzegła się od opowiadania o wydarzeniach porażających czy wręcz potwornych, ustanawiała zawsze pewne wartości, przyjmowała, że w świecie istnieje pewien porządek, mający swoje sensy. W Zagładzie niczego takiego nie było (Głowiński 50).

Rey trzykrotnie nazwie w Księdze rozbitków Zagładę potopem. Po raz pierwszy określenie to padnie w opowiadaniu Mój mit otwierającym zbiór. Przywołując różne zasłyszane historie dotyczące wojennych losów swojego brata, narrator stwierdzi: „Wszystkie wersje miały tę samą wartość, żadna z nich nie była pewniejsza od mego snu. Bądź co bądź, wszystkie wiadomości powstały podczas kataklizmu takiego jak potop" (Rey 11). W opowiadaniu Wesele w Waszyngtonie mowa będzie o rodzinie i przyjaciołach narratora, „którzy poginęli jak w potopie” (Rey 25), zaś w głównym bohaterze - ocalałym z Zagłady Michale - wydarzenia czasu wojny wywoływać będą następujące wspomnienia: „Potoki krwi, mordercy w gumowych butach, ludzie pożerani przez ludzi jak przez potop” (Rey 26).

Porównywanie Zagłady do biblijnego potopu może budzić nasze wątpliwości z wielu powodów. W semantyce biblijnej potop jest karą wymierzoną przez Boga ludziom w związku z ich zepsuciem moralnym. Niesie zagładę ludzkości, z której cało ujść ma Noe jako „człowiek prawy, [który - G.J.] wyróżniał się nieskazitelnością wśród współczesnych sobie ludzi” ( $\mathrm{Rdz} 6,9)^{2}$. W tym ujęciu narrator Księgi rozbitków przyrównywałby siebie do starotestamentowego budowniczego arki, z którym Bóg zawarł przymierze. Rodzi to jeszcze większy sprzeciw, gdy zdamy sobie sprawę, że za metonimią potopu stoi Holokaust, a więc opisany na kartach opowiadań Reya rozbitkowie - ocalali z Zagłady - to

2 Wszystkie przywoływane w tekście fragmenty Biblii pochodzą z Biblii Tysiąclecia Online, Poznań 2003 (www.biblia.deon.pl). 
boscy wybrańcy; ci, którzy nie sprawili, że „ziemia została skażona w oczach Boga" (Rdz 6, 11). Poczynione przez Reya porównanie zrównywałoby ponadto Boga ze sprawcami Holokaustu, to Bóg sprowadza bowiem w Starym Testamencie „na ziemię potop, aby zniszczyć wszelką istotę pod niebem, w której jest tchnienie życia” ( $\mathrm{Rdz} 6,17)$.

Decydując się na wykorzystanie właśnie takiego motywu, Rey stanął w całkowitej opozycji do radykalnych poglądów głoszonych między innymi przez rabina Richarda Rubinsteina, zdaniem którego Bóg umarł wraz z nadejściem Holokaustu. W myśleniu autora Księgi rozbitków Zagłada miałaby stanowić kolejną z tragedii dotykających Żydów na przestrzeni wieków, poczynając od „zburzenia Pierwszej i Drugiej Świątyni, przez wyprawy krzyżowe, wygnanie z Hiszpanii, masakrę Chmielnickiego, dziewiętnasto- i dwudziestowieczne pogromy” (Liszka 177), a więc wiązałaby się z „bogatą żydowską tradycją odpowiedzi na katastrofy” (Liszka 174). Przedstawiona przez autora Kropiwników koncepcja bliska byłaby myśleniu Ignaza Maybauma zaprezentowanemu przez żydowskiego teologa sześć lat po ukazaniu się zbioru opowiadań Reya w pracy The Face of God After Auschwitz (1965). Zdaniem rabina,

Zagłada stanowi trzecie churban (zniszczenie) po zburzeniu dwóch świątyń, jest wynikiem interwencji Boga w historię. [...] Maybaum nie twierdzi, że Szoa było karą za grzechy Izraela, w cierpieniu ofiar należy raczej dostrzec poświęcenie za grzechy innych, niebędących Żydami. Ostatecznie więc każda z wymienionych trzech katastrof przyczyniła się do postępu, który Maubaum rozumie w kategoriach moralnych - postępu w dążeniu ludzkości do osiągnięcia coraz większej doskonałości moralnej i misji, jaką ma w nim do spełnienia judaizm. Pierwsze dwie katastrofy, przyczyniając się do powstania diaspory, dały możliwość szerzenia prawd religii hebrajskiej poza wspólnotą żydowską, zaś Szoa wyznaczyło - wraz z unicestwieniem wschodnioeuropejskich Żydów - kres średniowiecza, epoki religijnych prześladowań i autorytaryzmu, przy czym nazizm był według Maubauma ostatnią kulminacją średniowiecznych tendencji opresyjnych. Trzecie churban wyznaczyło kres jednej epoki, lecz i początek kolejnej - nowoczesności, w której, jak podkreśla Maubaum, zwolniony od balastu średniowiecznego getta judaizm ma wciąż do spełnienia mesjańską misję (Liszka 189-190).

W tym ujęciu nazywanie przez Reya Zagłady katastrofą byłoby o tyle ważne, że, jak wskazuje Justyna Tabaszewska, katastrofa uznawana jest za swoisty punkt 
zwrotny, a jej „niszczący potencjał [...] kontrapunktowany jest przez potencjał twórczy, wyzwalający od narastających wraz z upływem czasu zależności" (Tabaszewska 23-24).

W kontekście rozważań na temat Księgi rozbitków jako specyficznej wersji robinsonady ważny okazuje się także aspekt kary za grzechy, który stanowi jeden z robinsonotopów. W powieści Defoe zatonięcie statku wzbudza w Robinsonie „poczucie winy i [...] sprowadza się do pojęcia kary boskiej za grzechy młodości” (Borkowska 351). Bohater powieści uznaje morską katastrofę „za wyrok Opatrzności” (Defoe 39). Czesław Miłosz zwraca ponadto uwagę na ambiwalentny charakter pobytu na wyspie - jest on zarówno łaską, jak i pokutą:

Ocalony ręką Opatrzności z odmętów morskich, gdy cała załoga ginie, budzi się z omdlenia na nieznanej ziemi. Pierwszym jego odruchem jest złorzeczyć losowi i rozpaczać. Wnikając jednak w siebie, odnajduje w sobie samym powód obecnego stanu: swój grzech. Przypadek nabiera charakteru słusznego wyroku i równocześnie łaskawej opieki. Wyrok Boga kazał mu znaleźć się na wyspie (Miłosz 56).

W klasycznej robinsonadzie realizującej model Defoe bezludna wyspa nosi znamiona utopii. Miłosz wskazuje, że „wyspa oznacza bezpieczeństwo jej mieszkańców od walk, sporów i wojen pozostałej ludzkości” (Miłosz 52). W warstwie symbolicznej wyspa wiąże się ze spokojem, szczęściem, pięknem, doskonałością i rajem (Kopaliński 488). Jak zauważa Miłosz, to właśnie „brak zagrożenia [...] właściwy wszelkiej legendzie o szczęściu” (Miłosz 52-53) decyduje o arkadyjskim charakterze robinsonowskiej wyspy. Przestrzeń, która początkowo budzi w bohaterach obawę, poczucie samotności i lęku oraz uznawana może być przez nich za karę za grzechy, ostatecznie okazuje się „wyspą łaski” (Miłosz 63). Robinson, choć wie, że jest „bez obrony i bez środków do odpierania przemocy człowieka lub zwierzęcia” (Defoe 42), zdaje sobie sprawę, że znalazł się „na wyspie, gdzie nie ma dzikich i drapieżnych bestii, jakie widywał [...] na brzegach Afryki” (Deofe 42).

Utopijny potencjał wyspy może jednak zostać ujawniony dopiero wtedy, gdy w bohaterze dokona się pozytywna przemiana polegająca na zmianie wyznawanych przez niego wartości. Motyw metamorfozy, którą „poprzedzają [...] smutne doświadczenia wyspiarskiego bytowania bohatera” (Ruszała 1998: 51), nie jest wyraźnie zaznaczony w Księdze rozbitków. Większość postaci opisanych w zbiorze nie potrafi dostosować się do nowych warunków życia. Pomimo że Ameryka staje się dla żydowskich rozbitków bezpieczną wyspą, chroniącą ich przed „drapieżnymi bestiami” (Defoe 42) w postaci hitlerowców, to pamięć o traumatycznej przeszłości uniemożliwia dokonanie się w nich wewnętrznej 
przemiany polegającej na ponownym odkryciu sensu i radości życia. W opisach kondycji poszczególnych bohaterów tomu wyraźnie uwidaczniają się symptomy syndromu pozagładowego.

Bohaterka opowiadania Nekrofilia - Jadwiga - „umiera z tęsknoty za [dawnym - G.J.] życiem" (Rey 37). Kobieta, której Zagłada odebrała dotychczasowe „otoczenie [...] gwałtownie i całkowicie” (Rey 37), pogrążona jest w permanentnej tęsknocie za tym, co utracone. Przebywając w Stanach Zjednoczonych, „nie potrafi, niby jaszczurka, odbudować reszty życia” (Rey 37). Jadwiga „z dnia na dzień znika, a lekarze nie mogą nic stanowczego stwierdzić, nie ustalili diagnozy” (Rey 37). Dla ocalałej z Holokaustu pobyt na zaoceanicznej „bezludnej wyspie” kończy się tragicznie - kobieta umiera. Inni ocalali „rozbitkowie” często płaczą (Michał z Wesela w Waszyngtonie, Artur z Lekarza), cierpią na bezsenność (narrator Mojego mitu), chorują na głęboką depresję (siostra tytułowej bohaterki opowiadania Felicja), niespodziewanie tracą przytomność (narrator z Nauczyciela), czują odrazę do życia (Janusz z Handlarza sztuki), czekają na kolejną wojnę, która sprawi, że „się ten świat raz na zawsze skończy” (Ziemia). Najbardziej wyrazistym przykładem ofiary nieprzepracowanej traumy jest Artur, bohater opowiadania Lekarz, który odmawia jedzenia oraz kładzie się „do łóżka z postanowieniem, aby umrzeć” (Rey 183). Pogrążony w rozpaczy i melancholii mężczyzna decyduje się wymierzyć sobie najsurowszą z możliwych kar - karę śmierci, która zakończy „krytyczny okres” (Rey 183) trwający w jego życiu od momentu przybycia do Ameryki. Bohaterowie Księgi rozbitków pozostają bierni, co odróżnia ich od Robinsona będącego „człowiekiem czynu (homo faber)" (Gazda 939).

O tym, że tytułowi rozbitkowie nie zaadaptowali się do życia w nowych warunkach, świadczy także ich wygląd. Na twarzy Jadwigi „w kilku głębokich zmarszczkach leżał ciężki smutek” (Rey 35). Kobieta „wyglądała jak człowiek nad grobem. [...] Twarz jej była szara i jakby podarta, oczy zapadłe, skóra na ramionach żółtawa i obwisła, cała postać skurczona, przygarbiona” (Rey 37). Kamil, postać, którą poznajemy na kartach Maski pośmiertnej, „robił wrażenie człowieka ubranego do trumny” (Rey 96). Trupio blada twarz mężczyzny sprawiała, że już za życia „nosił” on tytułową maskę pośmiertną. Również o samym narratorze Księgi rozbitków przeczytać możemy, że od czasu przybycia do Ameryki „wygląda jak trup, nie do poznania!” (Rey 159).

Wszystko to sprawia, że w zbiorze opowiadań autorstwa Reya widzieć należy raczej tak zwaną „realizację negatywną” (Gazda 940) robinsonady, która ma „charakter dyskusji z konwencją i mitologią” (Gazda 940) gatunku. Księga rozbitków byłaby przykładem robinsonady antyutopijnej. Wśród innych utworów realizujących ten model wymienić można między innymi Tajemniczą wyspe 
Juliusza Verne'a, Władcę much Williama Goldinga oraz Na srebrnym globie Jerzego Żuławskiego. Powieści te stanowią „negację mitu robinsonowskiego, odosobnienie i praca nie zmieniają bohatera na lepsze, lecz doprowadzają do obłędu bądź wyzwalają pierwotne instynkty" (Gazda 940). Na antyutopijny charakter opowiadań Reya kluczowy wpływ wywiera bez wątpienia poruszana przez autora tematyka, a także czas, $\mathrm{w}$ którym powstają. $\mathrm{xx}$ wiek przynosi nie tylko wielki kryzys gospodarczy, ale również dwie wojny o zasięgu ogólnoświatowym, a tym samym każe odrzucić marzenia o utopii, też na gruncie literatury, w szczególności zaś żydowskich narracji o Zagładzie wyrażających pokoleniową traumę Holokaustu.

Odnotowania wymaga jednak fakt, że dla tego typu robinsonad charakterystyczna jest swoista ambiwalencja antyutopii, która zauważalna jest także w przypadku Księgi rozbitków. Pod pewnymi względami Stany Zjednoczone okazują się dla żydowskich rozbitków miejscem arkadyjskim. Wpływ ma na to fakt, że to właśnie za sprawą miejsca, do którego trafili, udało im się przeżyć Zagładę. Tym samym Ameryka jawić może się jako „bezpieczna przystań” będąca schronieniem przed śmiercią.

Witold Ostrowski w haśle antyutopia zamieszczonym w Słowniku rodzajów i gatunków literackich zauważa, że „ambiwalencja utopii i antyutopii może powstać przez zastosowanie ironii" (Gazda 41). Właśnie z takim zabiegiem mamy do czynienia już w Prologu do Księgi rozbitków. Narrator-autor pisze o sobie: „Moją najwybitniejszą cechą jest, że żyję; podczas gdy moja rodzina przyjaciele, znajomi zginęli, ja ocalałem. Ci, którzy o tym wiedzą, rdzenni Amerykanie i inni, mówią: «To pan ma szczęście»..." (Rey 5). Owo szczęście jest jednak tylko pozorne, bowiem żydowskimi rozbitkami targają najróżniejsze emocje, łącznie z głębokim poczuciem winy, spowodowanym przeżyciem, podczas gdy inni Żydzi zginęli. Choć ocalały z Zagłady Michał stwierdza, że „trzeba pięknie żyć" (Rey 30), to postulat ten zdaje się pozostawać jedynie w sferze deklaracji. Mężczyzna podkreśla, że „my, to znaczy ci, co zostali, i ci, co zginęli, nie znosimy widoku żałoby po sobie; żałoba to dla nas jakby dalszy ciąg naszej męki” (Rey 30). Żałoba, choć przez ocaleńców od siebie odsuwana, niezaprzeczalnie stanowi jeden z kluczowych komponentów ich żydowskiej tożsamości.

Tylko w kilku bohaterach Księgi rozbitków dokonała się pozytywna przemiana będąca realizacją robinsonotopu związanego z metamorfozą rozbitka. Wśród nich jest opisany w Moim micie malarz - mężczyzna o promiennej, radosnej twarzy, która sprawiała wrażenie, jakby „tyle lat po wojnie jeszcze się cieszył, że pozostał przy życiu" (Rey 12). Jawna, niczym nieskrępowana radość ocaleńca wzbudza w pozostałych Żydach niesmak. Mężczyzna skupiony jest bowiem wyłącznie na własnym przetrwaniu, a w jego postawie brak refleksji na 
temat milionów ofiar Holokaustu. Przeczytamy o nim, że „cieszył się otwarcie, bezwstydnie, z niewinnością dziecka, może nawet trochę pyszałkowato” (Rey 12).

Z pozoru wydawać by się mogło, że także Marceli, „pełen siły i radości życiowej” (Rey 46) bohater Ziemi, opowiadając historię swojego przetrwania, wyśpiewuje „pieśń triumfalną” (Rey 46). Okazuje się jednak, że mężczyzna, który cudem przeżył wojnę na terenie Polski, po traumatycznych wydarzeniach z przeszłości „sam sobie stał się obcy; żył jakby poza sobą” (Rey 51); miał poczucie, że pomimo tego, iż ocalał, jego życie „nie należało do niego” (Rey 51). Ambiwalencja cechuje także postać Szulima, którego entuzjazm „rósł na głębokim smutku i wątpliwościach jak lilia wodna na bagnie” (Rey 123).

Szukając w Księdze rozbitków realizacji robinsonowskiego mitu metamorfozy, szczególnie dokładnie przyjrzeć należy się postaci narratora tomu. Kluczowe dla analizowanych nawiązań słowa odnaleźć można w opowiadaniu Chusta Naści:

Przez długi czas żyłem w Nowym Jorku tak, jakbym miał lada dzień podzielić los moich najbliższych, których pomordowali hitlerowcy i egzystencja moja była stanem przejściowym między życiem a śmiercią, niejako stanem półprzytomnym, częściowym odcięciem od rzeczywistości. Powoli jednak zaczęło we mnie brać górę życie i w końcu uświadomiłem sobie, że nie znajduję się na drodze do śmierci, ale żem ocalał [...]. Odkąd zrozumiałem, że mi przypadło w udziale życie, właściwie odkąd postanowiłem żyć, odczułem samotność, której przedtem nie czułem, przedtem bowiem byłem związany z zamordowaną rodziną. Wraz z uczuciem zupełnego osamotnienia szło uczucie, żem się na nowo urodził tu, w Nowym Jorku (Rey 99).

W przypadku narratora-autora ocalenie i znalezienie się po stronie życia, nie zaś śmierci, nie oznacza wcale przepracowania traumy i żałoby (zob. Ankersmit). Symboliczne przechylenie szali na stronę życia i powrót do rzeczywistości budzi w narratorze poczucie samotności. Paradoksalnie, to oczekiwanie na śmierć, która ostatecznie nie nadchodzi, sprawia, że mężczyzna odczuwa dużo większą łączność z zamordowanymi bliskimi. Z czasem bohater „rodzi się na nowo”. Nowy Jork, pełniący funkcję „,bezludnej wyspy”, zostaje oswojony, a w bohaterze ma szansę dokonać się wewnętrzna przemiana. Ma ona jednak charakter ambiwalentny, nie zaś jednoznacznie pozytywny. Typowe dla bohatera robinsonowskiego uczucie osamotnienia oraz tęsknoty za bliskimi, które towarzyszy mu tuż po rozbiciu się na bezludnej wyspie, narratora Księgi rozbitków dosięga już po momencie przełomowym, a więc po dopełnieniu się jego metamorfozy. 
To jeszcze jeden przykład tego, w jaki sposób opowiadania Reya przekształcają tradycyjny wzorzec robinsonady.

Rey, w przeciwieństwie do Defoe, nie lekceważy w swoim tomie „rzeczywistych psychicznych skutków samotności” (Watt 99). Bohaterów całego zbioru łączy poczucie wyobcowania oraz dojmującej samotności i tęsknoty za bliskimi Wielomilionowa metropolia, w której żyją ocalali z Zagłady Żydzi, jawi się im jako bezludna wyspa. Narrator opowiadania Matka Hitlera powie: „znalazłem się w Nowym Jorku sam, wykorzeniony, odcięty od rodziny, przyjaciół i znajomych w Polsce, z którymi nie wiadomo, co się stało" (Rey 191).

Zarówno w Robinsonie, jak i bohaterach Księgi rozbitków pojawiają się wątpliwości związane z tym, czy ocalenie faktycznie jest czymś, za co należy być wdzięcznym. Bohater powieści Defoe czynić będzie wyrzuty Bogu, którego wini za to, że jest człowiekiem „nieszczęśliwym, bezradnym, tak opuszczonym i przygnębionym, iż rzekłbyś, nie godzi się nawet dziękować za takie życie” (Defoe 39). Z kolei tytułowy bohater opowiadania Szulim pytać będzie: „Czy warto, czy warto było tak walczyć o życie?” (Rey 123). Podkreślić należy jednak, że choć Robinson początkowo pozbawiony jest jakiejkolwiek nadziei, widzi w sobie wygnańca „z ludzkiej społeczności” (Defoe 41), który na wyspie „nie ma żywej duszy, z którą by mógł rozmawiać albo doznać od niej pociechy” (Defoe 42), to ostatecznie „rozsądek brał [...] górę nad zwątpieniem, więc umiał znaleźć pociechę zestawiając złe i dobre strony [...] [swojego - G.J.] położenia” (Defoe 41). Tak nie dzieje się w przypadku żydowskich bohaterów Księgi rozbitków.

Ian Watt, badając powieść Defoe, odnotowuje, że potrzeby seksualne Robinsona Crusoe właściwie nie istnieją. Badacz wskazuje, że w momencie, gdy bohater „zauważa wreszcie brak «towarzystwa», modli się, aby Bóg zesłał mu kogoś na pocieszenie, ale, jak widzimy, potrzeba mu raczej niewolnika. Potem wraz z Piętaszkiem przeżywa idyllę bez udziału kobiet” (Watt 75). Nie inaczej sprawa ma się w przypadku bohaterów Księgi rozbitków. Narrator odczuwa „fizyczną odrazę” (Rey 36) do Jadwigi, bohaterki opowiadania Nekrofilia. Jak powie, „ja ją odtrąciłem. Ciągle ją przepraszałem, odchylałem się ciągle [...] od jej ciała" (Rey 36). Do cielesnych zbliżeń nie dochodzi w małżeństwie ocalałych opisanych na kartach Felicji. Ciało tytułowej bohaterki onieśmiela jej męża. Boi się on go dotknąć. W życiu kobiety także nie ma miejsca na seksualne pokusy postanawia ona żyć w celibacie. Podobną decyzję podejmuje inna z bohaterek zbioru - Stella, która „czuła fizyczną niechęć do mężczyzn” (Rey 171).

3 Ruszała wskazuje, że „lejtmotywem wszystkich adaptacji jest dręcząca Robinsona myśl o rodzicach. To ich wspomnienie nawet po powrocie do ojczyzny czyni go nieszczęśliwym” (Ruszała 1998: 53). 
O ile jednak w przypadku Robinsona seksualność wyparta zostaje „jako najsilniejszy z irracjonalnych czynników w życiu człowieka, stanowiący największą potencjalną groźbę dla racjonalnych ekonomicznych dążeń jednostki” (Watt 75), o tyle na postawie bohaterów opowiadań Reya piętno odcisnęła Zagłada. Obcowanie z ciałem ocalałych kobiet jawi się dla mężczyzn jako coś „brutalnego i bluźnierczego” (Rey 76), zaś w odczuciu bohaterek zbioru „wszystkie straszne przejścia wojenne były dziełem mężczyzny, wojna była rodzaju męskiego, ciało męskie było brutalne, niezdolne do miłości ni tkliwości” (Rey 171).

Watt zauważa ponadto, że w Robinsonie „kobiety mają do spełnienia tylko jedno zadanie" (Watt 76) - mają pomagać mężczyźnie w pracy i interesach; ich wygląd stanowi kwestię drugorzędną. Także dla narratora Księgi rozbitków kobiet nie musiało cechować zewnętrzne piękno, a co więcej,

ich brzydota miała sens. Rozparły je, zniekształciły dzieci, które z nich wyszły, które z nich jadły i którymi te matki stały teraz oblepione jak drzewa świeżymi owocami. Ich brzydota nie raziła, jak nie razi rosochate drzewo o pięknych owocach (Rey 121).

Inaczej rzecz ma się jednak w przypadku mężczyzn, których brzydota przygnębia narratora opowiadań, bowiem nie dostrzega on w niej żadnego sensu.

Próbując dokonać genologicznego doprecyzowania, należałoby uznać, że Księdze rozbitków najbliżej jest do robinsonady grupowej. Choć w zbiorze opowiadań Reya trudno byłoby wskazać charakterystyczną dla tego rodzaju utworów postać przywódcy, to bohaterem spajającym wszystkie siedemnaście opowiadań jest niewątpliwie narrator. Ruszała zwraca uwagę, że „w robinsonadzie grupowej są przygody wspólne i indywidualne. Razem tworzą mozaikę różnych wspólnych wydarzeń” (Ruszała 2000: 109). W przypadku Księgi rozbitków elementem wspólnym i spajającym wszystkie opowieści byłoby doświadczenie Zagłady oraz fakt bycia żydowskim ocalałym, podczas gdy historie poszczególnych rozbitków tworzyłyby niepowtarzalne, jednostkowe $\mathrm{i}$ indywidualne narracje.

To zebranie wszystkich opowiadań w jedną „księgę rozbitków” i antyutopijny charakter historii każą widzieć w zbiorze model robinsonady grupowej, charakterystyczny chociażby dla robinsonad Juliusza Verne’a, który „główną tezę Daniela Defoe: że człowiek może bytować poza społeczeństwem, uznawał za fałszywą" (Ruszała 1998: 83). Ponadto, jak celnie zauważa Ruszała,

postać Robinsona jako kategoria socjologiczna odnosi się do sytuacji grupy - większej liczby rozbitków, organizujących sobie życie zazwyczaj 
w trudnych warunkach egzystencjalnych, wymagających indywidualnej sprawności [...] oraz umiejętności współżycia (Ruszała 1998: 5).

Nie inaczej dzieje się w przypadku bohaterów Księgi rozbitków. Żydowscy ocaleńcy, którzy należą „do tego samego szczepu” (Rey 166), starają się trzymać razem - „widać w zgranym zespole łatwiej było zacząć odbudowę zrujnowanego życia..." (Rey 157).

Księgę rozbitków uznać można za specyficzną odmianę antyutopijnej robinsonady „miejskiej” (Żabski 826) lub też utworu robinsonopododobnego, który, wykorzystując i modyfikując wybrane robinsonotopy, wchodzi w nieoczywistą grę z tradycyjnym modelem Defoe. Podjęta przez Reya tematyka sprawia, że w zbiorze opowiadań widzieć wolno nowy, nieznany dotąd typ robinsonady, który nazwać można by robinsonadą holokaustową. W klasycznym modelu Defoe „Robinson [...] musi ujarzmić i ucywilizować naturę, nie tylko po to, by zapewnić sobie spokojny byt i dostatek, także po to, by ocalić swe człowieczeństwo" (Borkowska 351). W przypadku robinsonady holokaustowej bohaterowie z góry skazani są na porażkę - nie podejmują walki o swe człowieczeństwo, bowiem - jako Żydom - zostało im ono bestialsko odebrane w komorach gazowych i piecach krematoryjnych.

\section{| Bibliografia}

Ankersmit, Frank. „Pamiętając Holocaust. Żałoba i melancholia”. Przeł. Andrzej Ajschet, Andrzej Kubis, Joanna Regulska. Narracja, reprezentacja, doświadczenie. Studia z teorii historiografii. Red. E. Domańska. Kraków: Universitas, 2004. S. 403-426.

Biblia Tysiąclecia Online. Poznań: Wydawnictwo Pallottinum, 2003. Web. 14.02.2020. <www.biblia.deon.pl>

Borkowska, Ewa. „Robinson inny, czyli otchłanie samotności”. Literatura na Świecie 1 (1979). S. 350-356.

Buryła, Sławomir. „Zagłada widziana zza Oceanu”. Ruch Literacki 1 (2012). S. 63-80. Defoe, Daniel. Robinson Crusoe. Przeł. Józef Birkenmajer. Kraków: Wydawnictwo GREG, 2016.

Dunaj Bogusław, red. Stownik wspótczesnego języka polskiego. Warszawa: Wilga, 1996.

Gazda Grzegorz, red. Stownik rodzajów i gatunków literackich. Warszawa: Wydawnictwo Naukowe PwN, 2019.

Głowiński, Michał. Czarne sezony. Kraków: Wydawnictwo Literackie, 2018. Kopaliński, Władysław. Stownik symboli. Warszawa: Oficyna Wydawnicza RYTM, 2017. 
Liszka, Katarzyna. Etyka i pamięć o Zagładzie. Warszawa: Instytut Badań Literackich PAN, 2016.

Małczyński, Jacek. Krajobrazy Zagłady. Perspektywa historii środowiskowej. Warszawa: Instytut Badań Literackich PAN, 2018.

Miłosz, Czesław. „Legenda wyspy”. Literatura na Świecie 6 (1981). S. 52-65

Molisak Alina, Sekuła Aleksandra. „Wątki biblijne w literaturze o Zagładzie.

Wybrane przykłady”. Stosowność i forma. Jak opowiadać o Zagładzie?. Red.

M. Głowiński et al. Kraków: Universitas, 2005. S. 107-147.

Rey, Sydor. Księga rozbitków. Warszawa: Czytelnik, 1957.

Ruszała, Jadwiga. Robinson w literaturze polskiej. Teoria - historia - recepcja.

Słupsk: Wyższa Szkoła Pedagogiczna w Słupsku, 1998.

Ruszała, Jadwiga. Robinsonada w literaturze polskiej. Teoria - typologia - bohater - natura. Słupsk: Pomorska Akademia Pedagogiczna w Słupsku, 2000.

Sobol Elżbieta, red. Słownik języka polskiego PWN. Warszawa: PWN, 2018.

Tabaszewska, Justyna. „Katastrofy afektywne. Kategoria katastrofy w dyskursie ekokrytycznym i afektywnym - wstępne rozpoznania”. Poetyki ekocydu. $\mathrm{Hi}$ storia, natura, konflikt. Red. A. Ubertowska, D. Korczyńska-Partyka, E. Kuliś. Warszawa: Instytut Badań Literackich PAN, 2019. S. 23-40.

Tomczok, Marta. „Klimat Zagłady (w perspektywie powieści Pawła Huellego, Tadeusza Konwickiego, Andrzeja Kuśniewicza i Piotra Szewca)”. Teksty Drugie 2 (2017). S. 147-165.

Watt, Ian. Narodziny powieści. Studia o Defoe’em, Richardsonie i Fieldingu. Przeł. Agnieszka Kreczmar. Warszawa: Państwowy Instytut Wydawniczy, 1973.

Żabski Tadeusz, red. Słownik literatury popularnej. Warszawa: Wydawnictwo Uniwersytetu Wrocławskiego, 2006.

\section{| Abstrakt}

GAWEŁ JANIK

Ocalali z potopu. Ksiegga potopu Sydora Reya jako robinsonada holokaustowa

Artykuł stanowi próbę odczytania zbioru opowiadań Księga rozbitków (1959) autorstwa polsko-żydowskiego pisarza Sydora Reya jako specyficznego rodzaju robinsonady holokaustowej. Autor wskazuje, w jaki sposób utwór poruszający tematykę Zagłady przekształca tradycyjny model Defoe. Zwraca uwagę na zastosowaną w tomie metonimizację Holokaustu, który przedstawiony jest jako katastrofa, kataklizm czy klęska oraz zostaje przyrównany do starotestamentowego potopu. Badacz odczytuje Księge rozbitków jako realizację robinsonady antyutopijnej, w której klasyczny mit metamorfozy rozbitka nie zostaje zrealizo- 
wany, co sprawia, że bohaterowie opowiadań nieustannie balansują na granicy życia i śmierci.

Słowa kluczowe: Sydor Rey, Zagłada, Holokaust, robinsonada

\section{| Abstract}

GAWEŁ JANIK

Survivors of the Flood. The Book of the Wrecked by Sydor Rey as a Holocaust Robinsonade

The article is an attempt to read the set of stories The Book of Wrecked (1959) by the Polish-Jewish writer Sydor Rey as a specific type of Holocaust Robinsonade. The author indicates how the text deals with the subject of the Holocaust by transforming Defoe's traditional model. He draws attention to the metonymisation of the Holocaust used in the volume, which is presented as a disaster, cataclysm or defeat, and is compared to the Old Testament flood. The researcher reads the The Book of Wrecked as an implementation of anti-utopian Robinsonade in which the classic myth of the survivor's metamorphosis is not realized. As a result, the characters of the stories constantly balance on the border between life and death.

Keywords: Sydor Rey, Holocaust, Robinsonade

\section{| Nota o autorze}

Gaweł Janik - ur. 1994, doktorant literaturoznawstwa na Uniwersytecie Śląskim w Katowicach. Autor monografii Żydowskie (nie)męskości. O przedwojennej twórczości Adolfa Rudnickiego (Katowice 2019). Publikował artykuły oraz recenzje na łamach „Tekstów Drugich”, „Kultury Popularnej”, „Studia de Cultura”, „Narracji o Zagładzie”, „FA-artu”, „artPAPIERU” oraz tomów zbiorowych. Stypendysta Ministra Nauki i Szkolnictwa Wyższego. Laureat nagrody głównej II edycji konkursu na literaturoznawczą pracę magisterską w Instytucie Nauk o Literaturze Polskiej im. Ireneusza Opackiego Uniwersytetu Śląskiego oraz wyróżniony w xxıII Konkursie Prac Magisterskich im. Jana Józefa Lipskiego i viıı Konkursie im. Majera Bałabana na najlepsze prace magisterskie i doktorskie o Żydach i Izraelu.

E-mail: gaweljanik@wp.pl 